\title{
Morphology and ecological significance of intra-annual radial cracks in living conifers
}

\begin{abstract}
Intra-annual radial cracks were studied on 294 cross-sections of Norway spruce sampled at two forest sites in the eastern Alps (Italy) and from seven isolated trees in the Jura region (Switzerland). Cracks were occasionally accompanied by traumatic resin canals in the wood that was formed after the cracking. Most of the cracks, however, were without such canals. Traumatic resin canals are not significantly more abundant in tree rings formed after cracking, and their occurrence is not related to the cracking. Cracks developed when the cambium was inactive. Water imbalances during the early spring, due to transpiration losses and inadequate moisture supply from very cold roots, are the likely cause of these cracks.
\end{abstract}

Key words Dendroecology • Wood anatomy • Picea abies - Radial cracks - Frost drought

\section{Introduction}

Tree-ring records, mainly ring-width and maximum-density measurements, have enabled summer temperatures and precipitation regimes to be reconstructed for many regions. These proxy data, however, provide information about past climatic trends, rather than past extreme climatic events. Chronologies of extreme climatic events (e.g. frost, drought) would be valuable in studies on climate changes. More information about such events is needed, and might be supplied by studies of wood anatomical features, but the ecological significance of many such features remains unknown. For example, radial cracks in living trees might provide information about past extreme events, but they have never been investigated in a dendroclimatological context.

P. Cherubini $($ F. H. Schweingruber - T. Forster Swiss Federal Institute for Forest, Snow and Landscape Research (WSL), CH-8903 Birmensdorf, Switzerland
Radial cracks in the wood of living trees may be caused by internal stresses created mainly by frost, drought, wind or lightning (Knuchel 1947). The growing cells develop tension stresses along the grain of the wood and compression stresses develop in a circumferential direction. Substantial tangential shrinkage is therefore a prerequisite for the formation of frost- and drought-cracks (Kübler 1959; Archer 1987). The resulting cracks are mostly of the open type. Both wood and bark split open, necessitating the formation of callus wood before the wound can be closed (Larson 1994).

Frost cracks occur at temperatures which induce the freezing of water in cell walls. They are caused mainly by the cold shrinkage of wood due to internal drying which is produced by the freezing out of cell wall moisture into the lumens of wood cells. The tangential shrinkage is stronger than the shrinkage in a radial direction because of the wood's anisotropy, and leads to tangential tension strain, which triggers cracking (Duhamel du Monceau 1765, 1766; Caspary 1855, 1857; Müller-Thurgau 1886; Hartig 1896; Mayer-Wegelin et al. 1962; Ishida 1963; Kübler 1987). Formation of ice lenses in wet sapwood, the more rapid cooling of the stem's outer wood, and the expansion of freezing free water in living cell lumens may also occasionally be responsible for cracking (Schirp et al. 1974; Kübler 1983; Sano et al. 1989). The cracking may be enhanced by earlier injuries (Butin and Shigo 1981). Drought may also induce cracks through tangential shrinkage due to water loss (Nördlinger 1878; Barrett 1958; Cremer 1966; Aigner 1981). Cracking behaviour models of trees subjected to horizontal forces simulating wind stress have recently been developed, e.g. by Peters et al. (1985) and Ossenbruggen et al. (1986). The most common wind-induced damage is the development of tangential cracks (Busse 1910), although large radial resin-filled cracks have also been observed (Van der Syde 1976).

Whatever the condition causing cracking, radial cracks in living trees are of two types: the open type, with callous margin and overgrowing tissue, and the internal intraannual type. This paper deals only with the intra-annual cracks and we use the term "cracks" as an abbreviation for 
Table 1 Intra-annual radial ring cracks described in the literature

\begin{tabular}{|c|c|c|}
\hline \multicolumn{3}{|c|}{ Described as possible effect of summer drought } \\
\hline Nördlinger (1878) & Germany & Picea abies (L.) Karst. \\
\hline \multicolumn{2}{|c|}{ Reid and Mitchell (1951) New Zealand } & $\begin{array}{l}\text { Pseudotsuga taxifolia } \\
\text { (Poir.) Britt. }\end{array}$ \\
\hline Day (1954) & Wales and Scotland & Conifers \\
\hline Appel (1980) & Germany & Larix decidua Mill. \\
\hline Polge $(1982,1984)$ & France & $\begin{array}{l}\text { Pseudotsuga menziesii } \\
\text { Mirb. }\end{array}$ \\
\hline $\begin{array}{l}\text { Melin and Riou-Nivert } \\
\text { (1985) }\end{array}$ & France & $\begin{array}{l}\text { Pseudotsuga menziesii } \\
\text { Mirb. }\end{array}$ \\
\hline Yamanaka (1985) & Japan & $\begin{array}{l}\text { Chamaecyparis obtusa } \\
\text { Sieb. \& Zucc. }\end{array}$ \\
\hline $\begin{array}{l}\text { Caspari and Sachsse } \\
(1990)\end{array}$ & Germany & Picea abies (L.) Karst. \\
\hline \multicolumn{3}{|c|}{ Described as possible effect of frost } \\
\hline Pryor $(1947)$ & Australia & Pinus radiata D. Don \\
\hline Ishida (1963) & Japan & $\begin{array}{l}\text { Abies sachalinensis } \\
\text { (Schmidt) Mast. }\end{array}$ \\
\hline Dobrescu (1964) & Romania & Commercial timber \\
\hline \multicolumn{3}{|c|}{ Described as possible effect of frost drought } \\
\hline Lutz (1952) & Alaska & $\begin{array}{l}\text { Picea glauca (Moench) } \\
\text { Voss }\end{array}$ \\
\hline
\end{tabular}

intra-annual radial cracks. In the literature they have been referred to as splits, clefts, fissures, cleavages, checks and shakes. They have been observed in different conifers in several countries (Table 1). Summer drought and winter frost have been assumed as possible causes for the formation of the cracks, but their actual causes are still unknown because no causal relationship between the frequency of cracking and climatic conditions has been found (Amos 1954; Polge 1984).

The purpose of this paper is to describe crack morphology at the cellular level and to formulate hypotheses on the ecological significance of intra-annual radial cracks in living conifers in mountainous and subalpine environments.

\section{Materials and methods}

Cross-sections of Norway spruce [Picea abies (L.) Karst.] were sampled at three sites in two geographical regions (Italian eastern Alps and Swiss Jura). This paper mainly concerns two study sites (PAN1 and PAN2) which are located in the Paneveggio Forest in Trentino, in the eastern Alps (Dolomites, Italy). Both areas are on the same slope and have similar site characteristics. The plots are adjacent and differ only in elevation. PAN1 is at an elevation ranging from 1700 to $1800 \mathrm{~m}$ a.s.l. and PAN2 from 1800 to $1900 \mathrm{~m}$ a.s.l. The slope (gradient $30 \%$ ) is north-facing. The soil is a typical spodosol, on a quartz-porphyritic bedrock. The forest is dominated by Picea abies (L.) Karst. (99\%), with rare Larix decidua Mill. and Pinus cembra L. The stand has the following characteristics: 397 trees/ha, basal area about $50 \mathrm{~m}^{2}$ ha, average height $23 \mathrm{~m}$ and height of dominant trees $28 \mathrm{~m}$. The stand is uneven-aged and consists of three spatially fragmented cohorts: 1843-1846, 1855-1870, 1882-1892 (Cherubini et al. 1996). Calamagrostis villosa (Chaix) J. F. Gmelin, Vaccinium myrtillus L. and Sphagnum sp. are abundant. The mean annual temperature is $2.4{ }^{\circ} \mathrm{C}$ (1933-1978) at the Passo Rolle weather station, $2002 \mathrm{~m}$ a.s.l., $2.5 \mathrm{~km}$ from the site. The mean temperature in the coldest month (January) is $-5.1{ }^{\circ} \mathrm{C}$, and $10.4{ }^{\circ} \mathrm{C}$ in the warmest month (July). At the Paneveggio meteorological station, located at $1508 \mathrm{~m}$ a.s.l., approximately $2 \mathrm{~km}$ from the site, the average total annual precipitation is $1207 \mathrm{~mm}$ (1922-1978), with a maximum in summer. The snow cover lies in the forest for around 6 months.

In June 1993 two plots (PAN1 and PAN2) approximately 0.4 ha in area were identified and all the living trees labelled. The trees were then felled as part of a study of new silvicultural treatments for subalpine spruce stands by the "Istituto di Selvicoltura, Università di Firenze". A total of 266 cross-sections were taken from 135 trees (135 at stump height and 131 at $4 \mathrm{~m}$ ). Since $4 \mathrm{~m}$ is a common length for logs in the region, we took cross-sections at $4 \mathrm{~m}$ in order to enable normal logging of the timber. The uphill direction was marked on the basal cross-sections.

The third study area (LAS) is located in a forest-meadow at La Sagne (Jura, Switzerland). In April 1993, 28 cross-sections at $1.3 \mathrm{~m}$, $5.5 \mathrm{~m}, 10 \mathrm{~m}, 14 \mathrm{~m}$ and at $18.5 \mathrm{~m}$ were taken from seven isolated spruces, located between 1110 and $1240 \mathrm{~m}$ a.s.l. The site conditions of the seven isolated trees at La Sagne are described in Table 2.

All the cross-sections were seasoned in a fresh-air dry store, and sanded a few months later. Analyses were carried out on all crosssections. All cracks were dated to the year with the naked eye and with a stereo microscope (Wild M3Z Leica). On the basal cross-sections from the PAN2 site, the presence/absence of traumatic resin canals in all the tree rings was recorded. The occurrence of the cracks was then microscopically dated using 10-20 $\mu \mathrm{m}$ thick microsections (Leitz Aristoplan). The microsections were stained with safranin. Some were prepared without alcohol to preserve the resin. Fractured wood samples and microsections were subject to morphological investigations involving low-temperature scanning electron microscopy (LTSEM). The specimens were prepared according to Scheidegger et al. (1991). They were mounted with double-sided self-adhesive stickers (Herma, Germany) on aluminum stubs. Specimens were sputter-coated with $15 \mathrm{~nm}$ of platinum and examined using a Philips SEM 515.

\section{Results and discussion}

\section{Morphology}

In all cross-sections (at Paneveggio and at La Sagne), the cracks are narrow-elliptical, lenticular or diamond-shaped,

Table 2 Site description and occurrence of cracks at LAS

\begin{tabular}{|c|c|c|c|c|c|c|c|}
\hline $\begin{array}{l}\text { Tree } \\
\text { No. }\end{array}$ & $\begin{array}{l}\text { Elevation } \\
\text { m (a.s.1.) }\end{array}$ & $\begin{array}{l}\text { Slope } \\
\left({ }^{\circ}\right)\end{array}$ & Exposition & Water availabilitya & $\begin{array}{l}\text { Distance to nearest } \\
\text { competitor }(\mathrm{m})\end{array}$ & $\begin{array}{l}\mathrm{DBH} \\
(\mathrm{cm})\end{array}$ & $\begin{array}{l}\text { Cracks at } \\
1.30 \mathrm{~m} \mathrm{(n)}\end{array}$ \\
\hline 1 & 1110 & 5 & S-SW & Moist & 11 & 63 & 0 \\
\hline 2 & 1120 & 5 & E-SE & Moderately moist & 14 & 80 & 11 \\
\hline 3 & 1180 & 0 & plane & Moderately dry & 7 & 88 & 258 \\
\hline 4 & 1180 & 5 & $\mathrm{~S}$ & Moderately dry & 12 & 111 & 202 \\
\hline 5 & 1240 & 8 & $\mathrm{E}$ & Moderately dry & 12 & 77 & 4 \\
\hline 6 & 1240 & 10 & SE & Moderately dry & 6 & 89 & 22 \\
\hline
\end{tabular}

\footnotetext{
a Water availability as assessed by foresters, through field observations
} 
Fig. 1 An intra-annual radial crack with characteristic narrow-elliptical shape. The crack is filled with resin

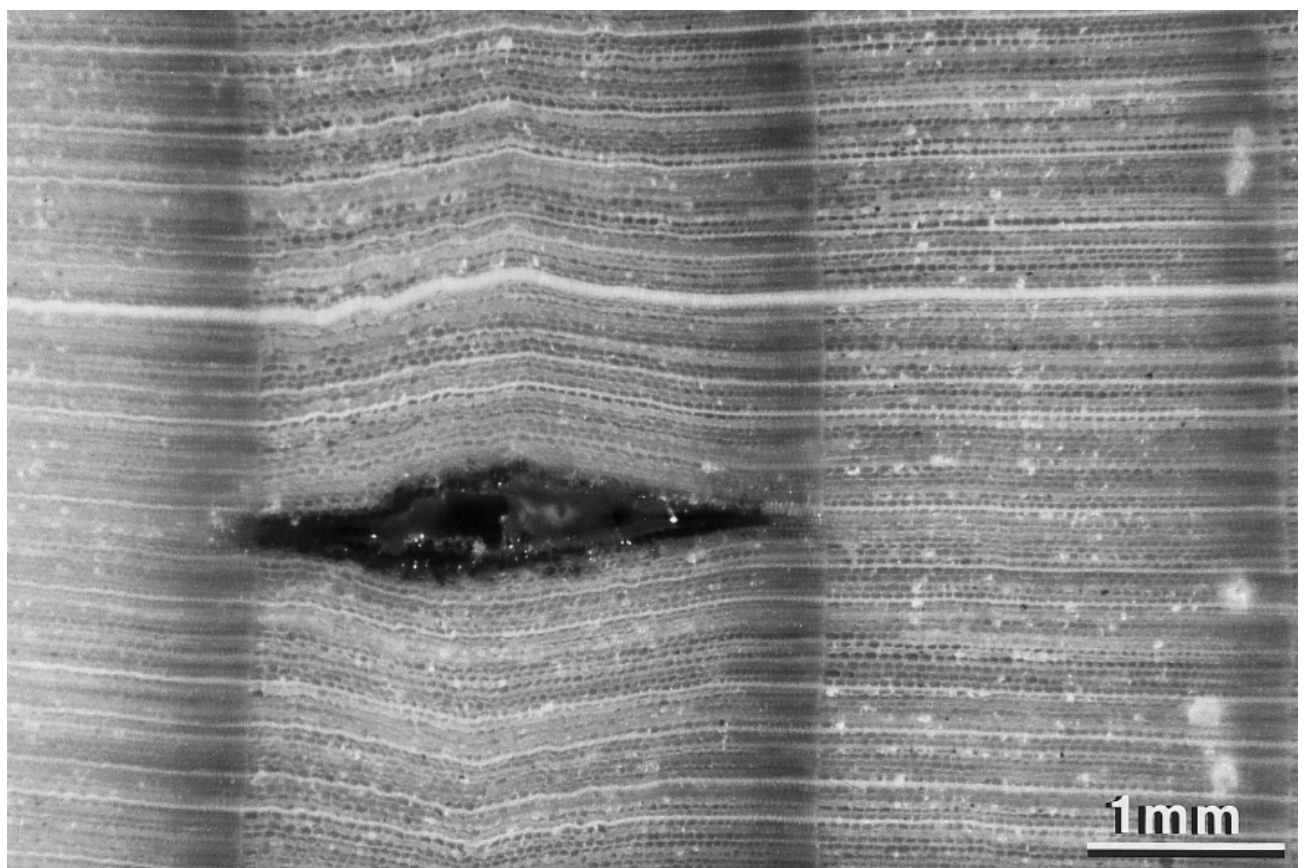

and are filled with resin (Fig. 1). The resin was excreted from the resin canal system. It circulated in a very liquid form in the wood through the pits, and penetrated the tracheids, mainly in the latewood. There is never an overgrowing or callous margin. The cracks in the stem are close and parallel to the rays (Fig. 2). At the cellular level, the cracks occur mostly in the zone of the middle lamella and of the primary wall (Fig. 3). Cracks start either in the late latewood of a tree ring or in the early earlywood of the following tree ring, and end in the late latewood of the tree ring formed in the year before. In some cases, the thin-
Fig. 2 Cracks are close and parallel to the rays. The latewood tracheids are filled with resin

Fig. 3 Tracheids cracked along the middle lamella and primary wall, near the rays. The latewood of the former tree ring appears to have stopped the crack

Fig. 4 A tangential crack along the border between tree rings. The thin-walled cells of the early earlywood are torn away from the thickwalled cells of the latewood of the previous tree ring. The latewood seemingly stopped the cracking. Resin penetrated in earlywood and latewood tracheids, moving through pits from nearby resin canals

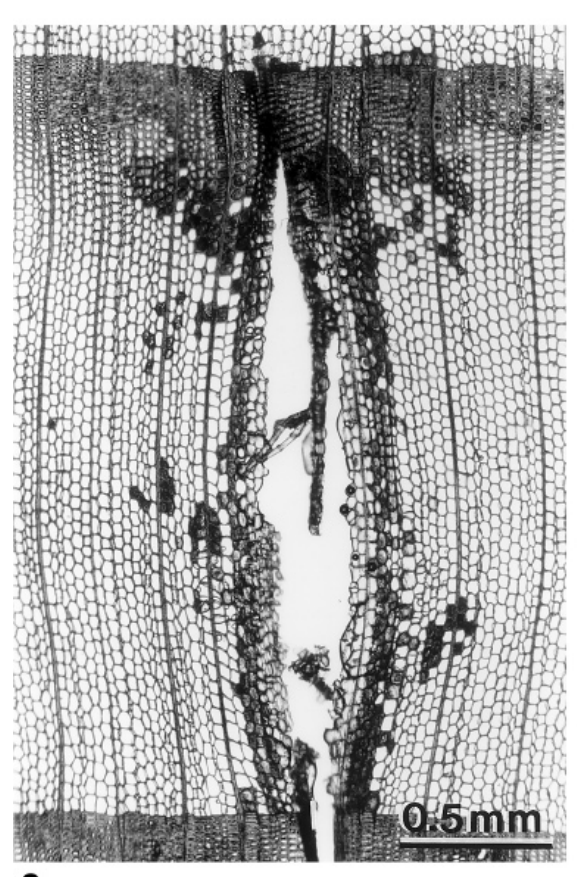

2

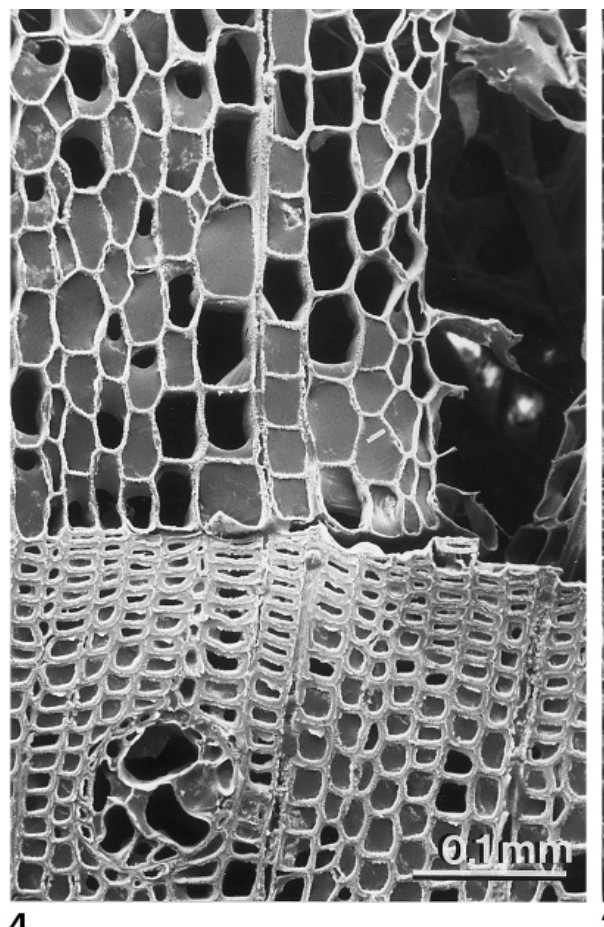

4

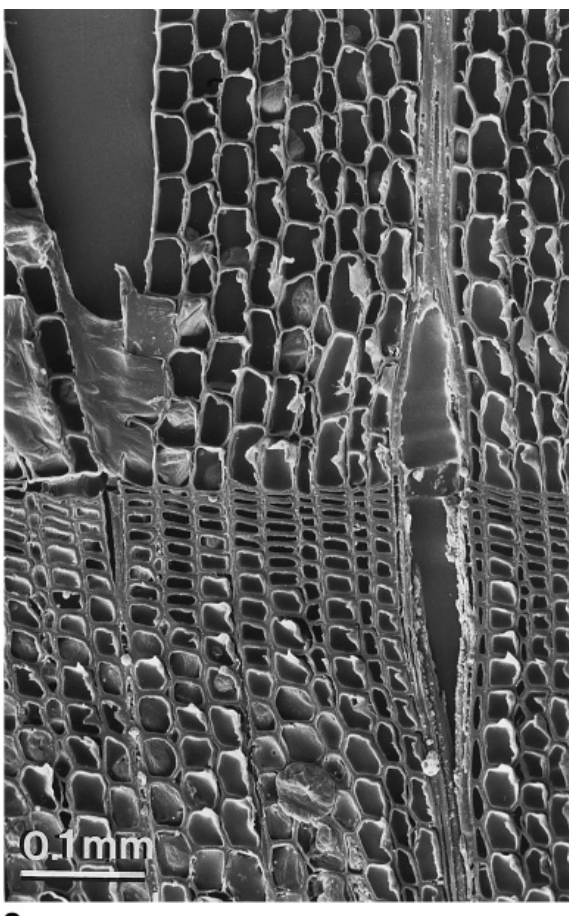

3 


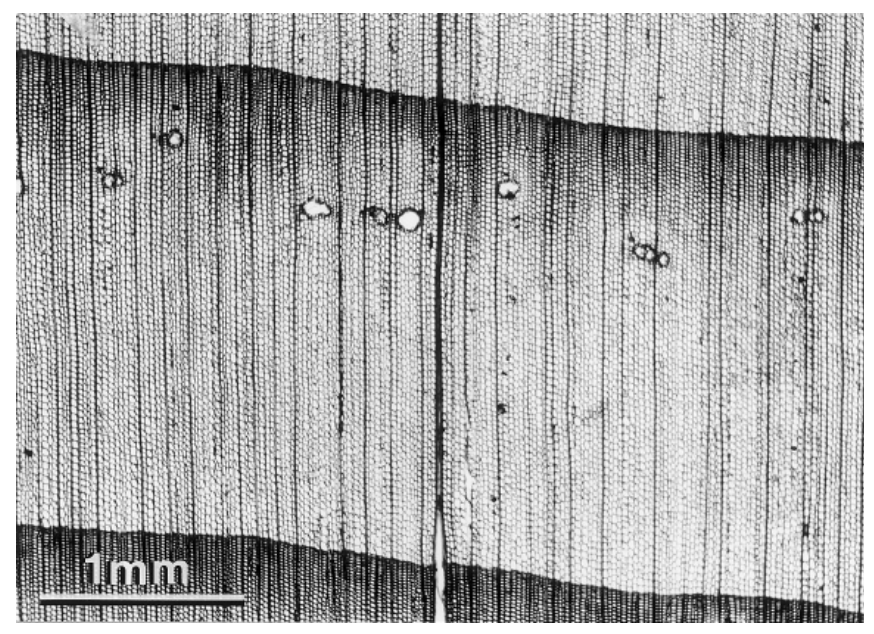

Fig. 5 Intra-annual radial crack with traumatic resin canals in the latewood of the following tree ring

walled cells of the early earlywood are torn away from the thick-walled cells of the latewood of the previous tree ring (Fig. 4). The latewood is more resistant than the earlywood, and seems to stop the cracking. No fungal attack has been observed in association with the cracks.

Many traumatic resin canals were observed when analysing the cracks $(n=443)$ on the basal cross-sections from PAN2. Since traumatic resin canals are produced in response to cambial injury (Larson 1994), cracks and traumatic resin canals might be due to the same physiological or environmental disturbance. Initially, we thought that the resin canals were produced by the cambium when the cracking occurred in the wood, and that they could help date the cracking. Several canals could be related to cracks, but for others it was difficult to establish such a connection because of the wide dispersal of the canals. The scattered distribution of the traumatic resin canals around the entire stem circumference made it difficult to relate their presence to the cracks. Some $(n=39 ; 9 \%)$ cracks were followed by traumatic resin canals, mostly in the latewood of the following tree ring $(n=34 ; 87 \%$; Fig. 5). However, an analysis of the occurrence of traumatic resin canals and cracks demonstrated that the two phenomena are not correlated (Fig. 6 and S. Ghosh, personal communication). Traumatic resin canals can be induced by a large number of both physical and environmental factors that cause either disturbance or injury to the cambium, and their association with cracks appears to be coincidental.

Most $(n=404 ; 91 \%)$ cracks did not have associated traumatic resin canals. There was no reaction in the cambium to the cracking.

\section{Occurrence of cracking}

At both the sites at Paneveggio, most cracks were concentrated in the tree ring for 1927 (Fig. 7). It therefore seems likely that the cracking was caused by an environmental factor. The other cracks occurred mainly in two periods: 1870 to 1890 , and 1920 to 1930 .

The frequency of cracks and of trees with cracks was highest at La Sagne (isolated trees) and lowest at Paneveggio (forest sites). At Paneveggio, there were more cracks at PAN2 (1800-1900 $\mathrm{m}$ a.s.l.) than at PAN1 (1700-1800 m a.s.1.; Table 3).

Fig. 6 Intra-annual radial crack and traumatic resin canal chronologies on the basal cross-sections from the PAN2 site

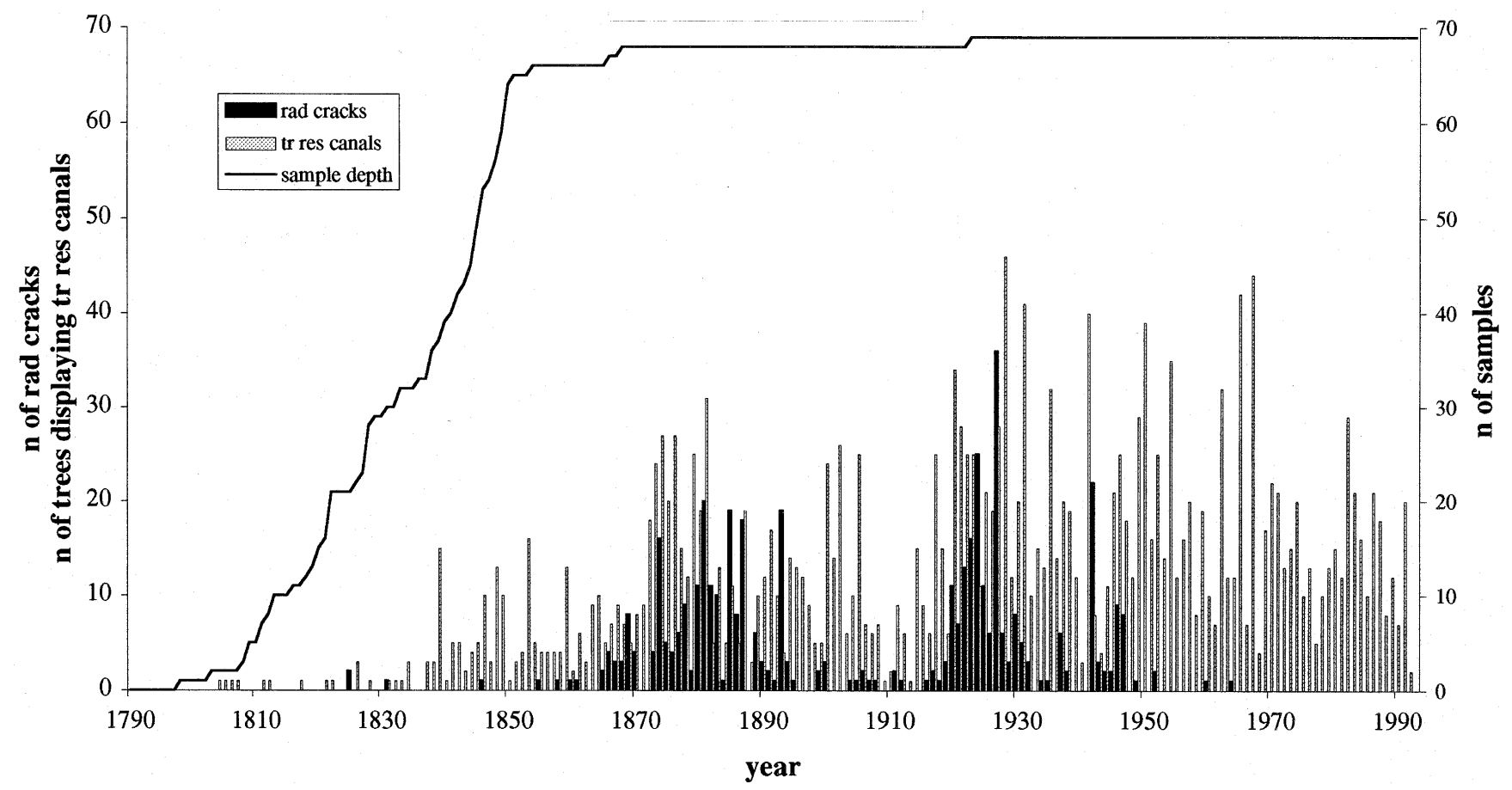


PAN1 - 4 m height -

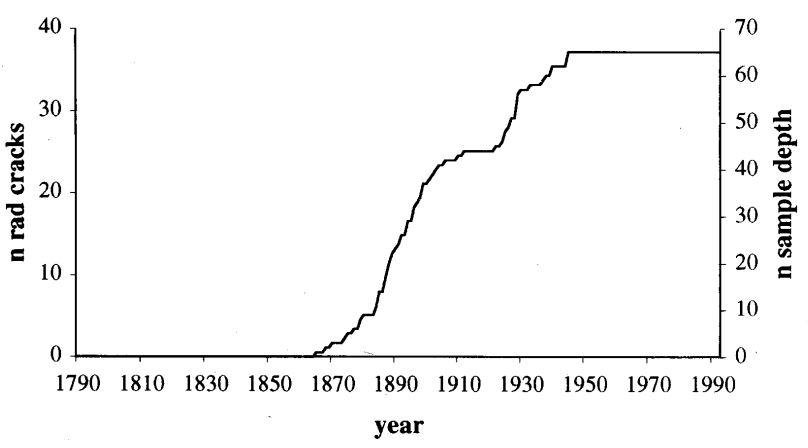

PAN1 - ground level -

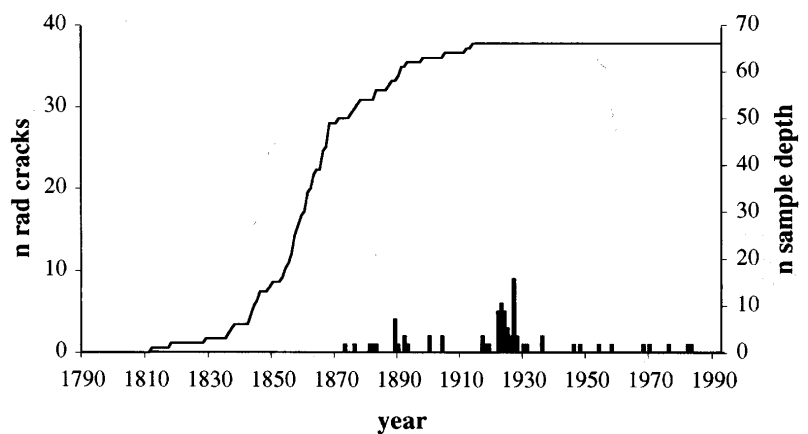

rad cracks

- sample depth

Fig. 7 Intra-annual radial crack chronologies and sample depth through time at Paneveggio

Within the sites at Paneveggio, there was no spatial pattern in the trees affected by cracks. In all the specimens (at Paneveggio and at La Sagne), there was no tendency for cracks to be concentrated on one side of the cross-sections. Cross-sections near the butt were more affected than crosssections higher up the stem and the inner part of crosssections more than the outer part (Table 4).

Cracks were found in both the heartwood and the sapwood. The presence of abundant resin shows that cracking occurred in living tissues with active resin canals in the sapwood. In other species, the cracks may be filled with cellular tissue, e.g. in Chamaecyparis obtusa (Yamanaka 1985), or may be empty, e.g. in Pseudotsuga menziesii (Polge 1982).

It is unclear whether the injury occurred only in the outermost ring or contemporaneously in several tree rings of the sapwood. However, the cracks are mainly distributed in specific time spans. Some events probably simultaneously influenced several rings, and only the weakest rings cracked. The structure of the wood is certainly a factor contributing to the crack, with a significant correlation between the number of cracks and earlywood width (positive) and percentage of latewood (negative) having been observed (Reid and Mitchell 1951; Lutz 1952; Boulet-
PAN2 - 4 m height -

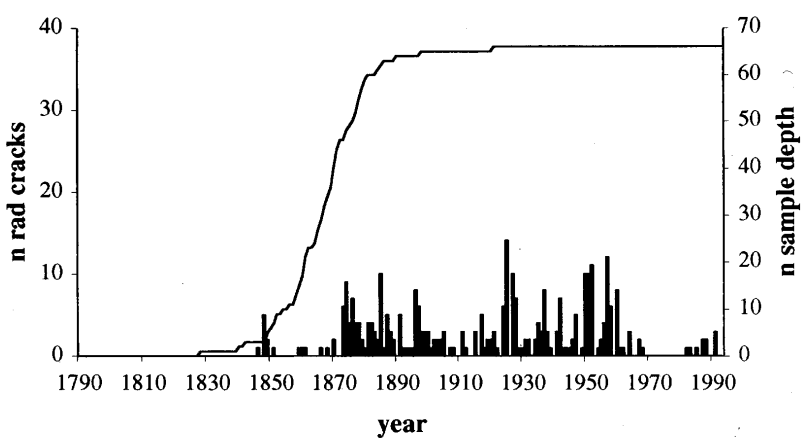

PAN2 - ground level -

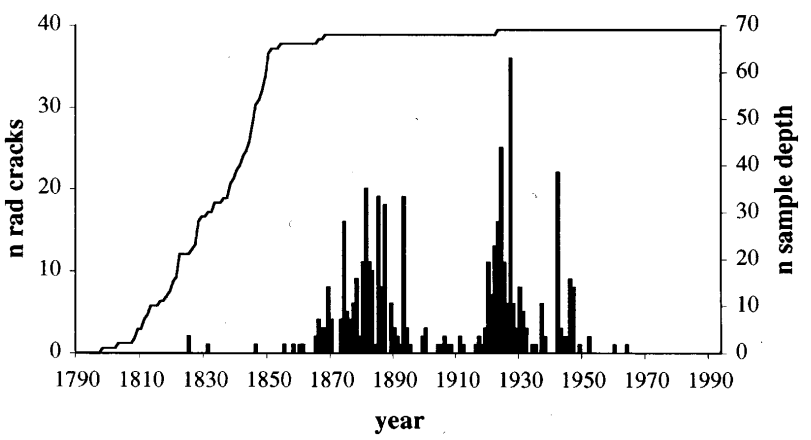

Table 3 Occurrence of trees with cracks and of cracks at PAN and at LAS

\begin{tabular}{lllllc}
\hline & $\begin{array}{l}\text { Sampling } \\
\text { height }\end{array}$ & No. of trees & $\begin{array}{l}\text { No. of trees } \\
\text { with cracks }\end{array}$ & $\begin{array}{l}\text { \% of trees } \\
\text { with cracks }\end{array}$ & $\begin{array}{l}\text { No. of } \\
\text { cracks }\end{array}$ \\
\hline PAN1 & $\begin{array}{l}\text { at stump } \\
\text { height } \\
\text { at } 4 \mathrm{~m}\end{array}$ & 66 & 8 & 12 & 66 \\
PAN2 & 65 & 0 & 0 & 0 \\
& at stump & 69 & 24 & 35 & 443 \\
height & & & & \\
LAS & at $4 \mathrm{~m}$ & 66 & 27 & 41 & 319 \\
& $\begin{array}{l}\text { at } 1.30 \mathrm{~m} \\
\text { at } 5.50 \mathrm{~m}\end{array}$ & 7 & 5 & - & 402 \\
& at $10.00 \mathrm{~m}$ & 7 & 5 & - & 162 \\
at $14.00 \mathrm{~m}$ & 7 & 3 & - & 35 \\
at $18.50 \mathrm{~m}$ & 7 & 1 & - & 4 \\
\hline
\end{tabular}

Gercourt 1986; Caspari and Sachsse 1990). In addition, Polge (1982) found a very significant negative correlation between the frequency of cracks and minimal density.

\section{Dating of cracking}

The cracks may be followed by traumatic resin canals but this appears coincidental. Thus, the presence of traumatic resin canals in the latewood does not indicate that the cracking developed at the time of latewood formation. 
Table 4 Distribution of cracks at LAS. Number of cracks and diameter at which they were found, at different heights

\begin{tabular}{|c|c|c|c|c|c|c|c|c|c|c|c|c|c|c|}
\hline \multirow{2}{*}{$\begin{array}{l}\text { Tree No. } \\
\text { Cracks }\end{array}$} & \multicolumn{2}{|l|}{1} & \multicolumn{2}{|l|}{2} & \multicolumn{2}{|l|}{3} & \multicolumn{2}{|l|}{4} & \multicolumn{2}{|l|}{5} & \multicolumn{2}{|l|}{6} & \multicolumn{2}{|l|}{7} \\
\hline & No. & Diameter & No. & Diameter & No. & Diameter & No. & Diameter & No. & Diameter & No. & Diameter & No. & Diameter \\
\hline \multicolumn{15}{|l|}{ Height } \\
\hline 18.50 & & & & & & & & & & & 2 & 22 & & \\
\hline 14.00 & & & 0 & / & 0 & / & 0 & / & 0 & / & 4 & 28 & 0 & / \\
\hline 10.00 & 0 & / & 0 & / & 17 & 28 & 5 & 28 & 0 & / & 13 & 46 & 0 & / \\
\hline 5.50 & 0 & / & 4 & 16 & 106 & 38 & 17 & 26 & 2 & 44 & 33 & 52 & 0 & / \\
\hline
\end{tabular}

Since there was no reaction in the cambium, the cracks must have developed after the latewood formed and before growth was initiated the following spring. They appear to have formed during the dormant season (fall, winter or early spring), when the cambium was inactive.

Possible ecological causes of intra-annual cracks

Wind, drought and frost are all possible causes for cracking. Wind can be excluded, because trees exposed to wind would be more affected than trees growing in sheltered sites and there would be a tendency for the cracks to occur in a certain direction within the cross-section. However, there were no such patterns in the distribution of affected trees, or in particular quadrants of the cross-sections, as also observed by Reid and Mitchell (1951), Lutz (1952) and Boulet-Gercourt (1986).

Drought is another possible cause of cracking. At La Sagne, water availability seems to play a key role (Table 2). According to Polge (1982,1984), cracking is associated with the removal of water from soil, because cracks are found only in wood zones with a very low moisture and never in normal moist wood. Consequently, microclimatic soil dryness may be responsible for the cracking. However, in this study, cracking was found to have occurred during the dormant season, and summer drought can therefore be excluded. If a drought period is responsible for the cracks, then it should have occurred during the late autumn, winter or early spring.

The absence of a closed canopy, proximity to the ground and a thin bark all favour cracking. Consequently, frost might be responsible. However, the direct effect of frost can be excluded because no correlation was found between the occurrence of cracking and extreme minimal temperatures or frost days. Moreover, frost events usually produce open type cracks or, during the vegetation period, frost rings which characteristically show underlignified and collapsed tracheids (Glerum and Farrar 1966; LaMarche and Hirschboeck 1984). Neither open-type cracks nor frost rings were found.

The most likely explanation is that cracking results from an imbalance between water loss and water replenishment during the dormant season. Such conditions may also occur after frost periods without extreme values (Mayer et al. 1988). At the study sites such periods of imbalance may occur during the early spring at the start of the growing period, as the day temperature rapidly increases and the snow-covered ground remains frozen, or at least very cold. Conifer needle temperatures can be elevated above freezing by intense solar radiation, the air can be extremely dry, transpiration losses can be great, and water lost through transpiration cannot be resupplied from frozen or very cold roots. Cold soil reduces water uptake in three ways: directly, by decreasing the permeability of the roots to water, and indirectly, by increasing the viscosity of water, which slows its movement through both soil and roots, and by reducing root respiration (Kramer and Kozlowski 1979). Absorption of water from the soil is prevented by frozen ground, and is greatly restricted by low soil temperatures (Tranquillini 1979). Replacement of transpiration loss is inhibited, especially in those species which have a superficial root system (e.g. Picea abies; Mayer et al. 1988). We believe that the resulting water deficit generates tangential shrinkage leading to the formation of cracks. This damage can therefore probably be ascribed to frost and/or winter desiccation. Crown damage caused by frost drought and winter desiccation in conifers has been widely reported in the literature (Curry and Church 1952; Friedland et al. 1984; Boyce et al. 1991; Herrick and Friedland 1991), but no damage to the wood structure has previously been described.

Acknowledgements This research was financially supported by the Swiss Federal Institute for Forest, Snow and Landscape Research (WSL), the Istituto di Selvicoltura, Università di Firenze (Italy) and the Parco Naturale di Paneveggio e Pale di San Martino (Italy). The Servizi Forestali Provincia di Trento (Italy) provided technical support during the sampling. We acknowledge Dieter Eckstein (University of Hamburg, Germany) and Ladislav J. Kucera (ETH Zürich, Switzerland) for helpful discussions. Many colleagues at our Institute (WSL) helped us in some way. We thank Nino Kuhn and Arnold Streule for suggestions, Reinhard Lässig who kindly provided material from isolated trees, and Christoph Scheidegger who provided support with the scanning electron microscope. We are grateful to Sucharita Ghosh for statistical advice and to Rudolf Häsler and John Innes for valuable comments on the manuscript.

\section{References}

Aigner F (1981) Bestandes- und Holzschäden durch Rissbildungen an Fichte. Allg Forstz 36: 720-722

Amos GL (1954) Radial fissures in the early wood of conifers. Aust J Bot 2: $22-34$

Appel R (1980) Radialrisse an jungen Lärchen. Forstarchiv 51: 93-96 
Archer RR (1987) Growth stresses and strains in trees. Springer, Berlin Heidelberg New York

Barrett DK (1958) Cracking in the main stem of noble fir at Lethen, Nairnshire. Scott For 12: 187-193

Boulet-Gercourt B (1986) Fentes des arbres sur pied chez Abies grandis (Lindl.). DEA, INRA-CNRF, Station de Recherches sur la Qualité des Bois, Nancy

Boyce RL, Friedland AJ, Webb ET, Herrick GT (1991) Modelling the effect of winter climate on high-elevation red spruce shoot water contents. For Sci 37: 1567-1580

Busse (1910) Frost-, Ring- und Kernrisse. Forstw Cbl 32: 74-84

Butin H, Shigo AL (1981) Radial shakes and "frost cracks" in living oak trees. USDA For Serv Res Pap NE-478, NE For Exp Stn, Broomall

Caspari CO, Sachsse H (1990) Rissschäden an Fichte. Forst Holz 45: 685-688

Caspary R (1855) Über Frostspalten. Bot Ztg 13: 449-462; 473-482; $489-500$

Caspary R (1857) Neue Untersuchungen über Frostspalten. Bot Ztg 15: $329-335 ; 345-350 ; 361-371$

Cherubini P, Piussi P, Schweingruber FH (1996) Spatiotemporal growth dynamics and disturbances in a subalpine spruce forest in the Alps: a dendroecological reconstruction. Can J For Res 26: 991-1001

Cremer KW (1966) Field observations of injuries and recovery in Eucalyptus rossii after a record drought. Aust For Res 2: 3-21

Curry JR, Church TW (1952) Observations of winter drying of conifers in the Adirondacks. J For 50: 114-116

Day WR (1954) Drought crack of conifers. Imperial Forestry Institute, Oxford

Dobrescu GM (1964) Gelivura. Forme, defecte derivate si asociate. Ind Lemnului 12: 470-474

Duhamel du Monceau (1765) Die Naturgeschichte der Bäume. 2. Teil. Übers. C.C. Ölhafen von Schöllenbach, Nürnberg

Duhamel du Monceau (1766) Die Naturgeschichte der Bäume. 3. Teil. Übers. C.C. Ölhafen von Schöllenbach, Nürnberg

Friedland AJ, Gregory RA, Kärenlampi L, Johnson AH (1984) Winter damage to foliage as a factor in red spruce decline. Can J For Res 14: $963-965$

Glerum C, Farrar J L (1966) Frost ring formation in the stems of some coniferous species. Can J Bot 44: 879-886

Hartig R (1896) Innere Frostspalten. Forst Naturw Z 5: 483-488

Herrick GT, Friedland AJ (1991) Winter desiccation and injury of subalpine red spruce. Tree Physiol 8: 23-36

Ishida S (1963) On the development of frost cracks on "Todomatsu" trunks, Abies sachalinensis, especially in relation to their wetwood. Res Bull Coll Exp For Hokkaido Univ 22: 273-373

Knuchel H (1947) Holzfehler. Werner Classen, Zürich

Kramer PJ, Kozlowski TT (1979) Physiology of Woody Plants. Academic Press, New York
Kübler H (1959) Die Ursache der Wachstumsspannungen und die Spannungen quer zur Faserrichtung. Holz Roh-Werkst 17: 1-9

Kübler H (1983) Mechanism of frost crack formation in trees. A review and synthesis. For Sci 29: 559-568

Kübler H (1987) Origin of frost cracks in stems of trees. J Arbor 13: 93-97

LaMarche VC, Hirschboeck KK (1984) Frost rings in trees as records of major volcanic eruptions. Nature 307: 121-126

Larson PR (1994) The vascular cambium. Development and structure. Springer, Berlin Heidelberg New York

Lutz HJ (1952) Occurrence of clefts in the wood of living white spruce in Alaska. J For 50: 99-102

Mayer H, König C, Rall A (1988) Identifikation von Witterungsereignissen mit pflanzenphysiologischer Stresswirkung für Waldbäume. Forstw Cbl 107: 131-140

Mayer-Wegelin H, Kübler H, Traber H (1962) Über die Ursache der Frostrisse. Forstw Cbl 81: 129-137

Melin N, Riou-Nivert P (1985) La microfissuration du bois de douglas: un défaut peu connu. Forêt-Entreprise 32: 26-29

Müller-Thurgau H (1886) Über das Gefrieren und Erfrieren der Pflanzen. Landwirtsch Jahrb 15: 483

Nördlinger H (1878) Trockenrisse (falsche Frostrisse) an der Fichte. Auch ein Grund der Rothfäule. Cbl Ges Forstw 4: $281-284$

Ossenbruggen PJ, Peters MA, Shigo AL (1986) Potential failure of a decayed tree under wind loading. Wood Fiber Sci 18: 168-186

Peters MA, Ossenbruggen PJ, Shigo AL (1985) Cracking and failure behavior models of defective balsam fir trees. Holzforschung 39: $125-135$

Polge H (1982) Quelques observations sur des fissures radiales dans le bois de douglas. Ann Sci For 39: 399-406

Polge H (1984) Nouvelles observations sur les fissures radiales du douglas. Rev For Fr 36: 453-458

Pryor LD (1947) Damage to Pinus radiata by climatic agents. Aust For 11: $57-64$

Reid JS, Mitchell MT (1951) Internal checks occurring in Douglas fir from two sites. For Prod Res Not (N Z) 1: 2-10

Sano Y, Imagawa H, Ohtani J, Fukazawa K (1989) Observations of frost crack development in the plantation trees of Abies sachalinensis. Res Bull Coll Exp For Hokkaido Univ 46: 315-341

Scheidegger C, Günthardt-Goerg M, Matyssek R, Hatvani P (1991) Low-temperature scanning electron microscopy of birch leaves after exposure to ozone. J Microsc (Oxford) 161: 85-95

Schirp M, Kübler H, Liese W (1974) Untersuchungen an Baumscheiben über das Entstehen von Frostrissen. Forstw Cbl 93: 127-136

Tranquillini W (1979) Physiological ecology of the alpine timberline. Springer, Berlin Heidelberg NewYork

Van der Syde HA (1976) Resin-infiltrated heart shakes in Pinus elliottii grown in the Transvaal. S Afr For J 97: 29-35

Yamanaka K (1985) Abnormal tissue in swollen stemwood of Chamaecyparis obtusa Sieb. \& Zucc. IAWA Bull n.s. 6: 53-60 